Monika Gorzelak

Urząd Statystyczny w Katowicach

m.gorzelak@stat.gov.pl

\title{
Rola statystki publicznej w procesie monitorowania zrównoważonego rozwoju kraju. Aplikacja Wskaźniki Zrównoważonego Rozwoju w kontekście pomiaru jakości życia
}

Artykuł nadesłany: 22 czerwca 2017 r.; artykuł zaakceptowany: 15 grudnia 2017 r.

JEL Classification: Q01, I10

Keywords: sustainable development, sustainable development indicators, quality of life, public health

\section{Abstract}

The role of official statistics in the process of monitoring sustainable development of the country: Sustainable Development Indicators Application in the context of life quality measurement

The present paper is concerned with measuring public health on the national level both as a determinant of life quality and as an area of sustainable development in its social dimension. The Sustainable Development Indicators Application is a publicly available tool for monitoring the condition of society. It was developed in the Statistical Office in Katowice in cooperation with the Statistical Office in Wroclaw, and launched on the official website of the Central Statistical Office of Poland in February 2016. The SDI Application is a proposal of official statistics for disseminating and presenting information on the sustainable development of the country. It includes a set of indicators grouped into areas within four domains: social, economic, environmental and institutional-political on the national, regional and local levels. SD indicators on the national list monitor goals referring to sustainable development, set out in national strategic documents, including quality of life, which underlies social, economic and institutional-political development of the country. Currently, the Polish SDI set is being further developed according to the guidelines outlined in the 2030 Agenda adopted at the UN Summit in 2015.

Ekonomia — Wroclaw Economic Review 23/4 (2017)

(C) for this edition by CNS 


\section{Wstęp}

Celem niniejszego artykułu jest przedstawienie zasobów informacyjnych aplikacji Wskaźniki Zrównoważonego Rozwoju (WZR) w kontekście pomiaru jakości życia na poziomie kraju. Wśród poruszonych zagadnień zostaną zaprezentowane dziedziny $\mathrm{z}$ ładu społecznego jako obszary wymagające monitorowania w ramach zrównoważonego rozwoju oraz determinanty jakości życia wraz ze wskaźnikami do ich pomiaru. Uwzględniając tezę konferencji WAICHL-2017, zgodnie z którą:

[z]drowie jest wartością pozwalającą człowiekowi realizować funkcje życiowe oraz czerpać satysfakcję, ucząc się, pracując i wypełniając obowiązki względem otoczenia,

w artykule dokonano analizy mierników monitorujących dziedzinę ,,zdrowie publiczne". Wskaźniki do pomiaru stanu zdrowia społeczeństwa na poziomie kraju w aplikacji WZR obejmują:

- oczekiwane trwanie życia osób w wieku 65 lat w zdrowiu,

- standaryzowane współczynniki umieralności z powodu chorób układu krążenia, nowotworów złośliwych oraz przewlekłych chorób dolnych dróg oddechowych i cukrzycy,

— Europejski Konsumencki Indeks Zdrowia EHCI,

— narażenie ludności miejskiej na ponadnormatywne oddziaływanie pyłu $\mathrm{PM}_{10}$

— narażenie ludności miejskiej na powietrze zanieczyszczone ozonem.

Analiza wartości poszczególnych mierników monitorujących łącznie dziedzinę zdrowia publicznego w aplikacji WZR pozwoli na uzyskanie kompleksowego obrazu kluczowej determinanty jakości życia na poziomie kraju.

\section{Jakość życia w koncepcji zrównoważonego rozwoju}

Zdrowie w polskiej statystyce publicznej definiowane jest zgodnie z Konstytucją Światowej Organizacji Zdrowia (WHO — World Health Organisation) i utożsamiane ze ,stanem zupełnej pomyślności fizycznej, umysłowej i społecznej, a nie jedynie brakiem choroby lub ułomności” (Dz.Urz. UE z 1948 r., s. 1232). Stan zdrowia $\mathrm{w}$ tak szerokim rozumieniu uwarunkowany jest wieloma powiązanymi z sobą czynnikami, wśród których można wyróżnić cztery główne grupy, tak zwane pola zdrowia (ang. health fields) w koncepcji Marca Lalonde'a (Wysocki, Miller 2003, s. 57):

1. zachowania (ang. lifestyle);

2. środowisko (ang. environment):

- fizyczne (naturalne oraz wykreowane przez człowieka),

- społeczne, 
- pracy,

- nauki;

3. biologia - czynniki genetyczne oraz ogół systemów wewnętrznych w organizmie człowieka (ang. human biology);

4. działania opieki zdrowotnej (ang. health care organisation) (Lalonde 1981, s. 31).

Jako pierwszy dokument strategiczny w świecie zachodnim raport Lalonde’a stanowi kamień milowy w ewolucji pojęcia zdrowia oraz jego implementacji, w tym na gruncie statystyki (Hanckock 1985, s. 10). Zawarta w nim idea pól zdrowia wpłynęła na kształt i operacjonalizację przyszłych polityk zdrowotnych (Włodarczyk 1996, s. 194-195), w tym Narodowych Programów Zdrowia (NPZ)1.

Definicja zdrowia WHO oraz stanowiące jej konkretyzację pola zdrowia Lalonde'a ${ }^{2}$ wpisują się w paradygmat zrównoważonego rozwoju, wiążąc czynniki społeczno-ekonomiczno-środowiskowe ze zdrowiem publicznym. Ów związek merytoryczny podkreśla dodatkowo fakt objęcia przez Gro Haarlem Brundtland (określanej mianem Matki Zrównoważonego Rozwoju - Mother of Sustainability) funkcji Dyrektor Generalnej WHO w lipcu 1998 roku. W latach poprzedzających przejęcie sterów Światowej Organizacji Zdrowia (1984-1987) była Minister Zdrowia i Premier Rządu Norwegii przewodniczyła pracom Światowej Komisji ds. Środowiska i Rozwoju (WCED - World Commission on Environment and Development), znanej między innymi z opracowania koncepcji zrównoważonego rozwoju. Zgodnie z definicją zawartą w raporcie finalnym WCED zrównoważony rozwój

oznacza taki proces zmian, w którym eksploatacja zasobów, kierunki inwestowania, kierunki postępu technicznego i zmiany instytucjonalne pozostają w harmonii i zachowują bieżąco i na przyszłość możliwości zaspokojenia ludzkich potrzeb i aspiracji. (Nasza wspólna przyszłość 1991, s. 71)

Reasumując, należy zauważyć, że u podstaw zrównoważonego rozwoju leży antropocentryczna koncepcja jakości życia, wyrażona w zasadzie solidarności wewnątrz- i międzypokoleniowej. Koncepcja jakości życia opartej na umiarkowanym antropocentryzmie uznaje podmiotowość każdej istoty ludzkiej bez względu na czas i miejsce, pochodzenie, płeć, wiek oraz inne cechy społeczno-demograficzne. Sprawiedliwość międzygeneracyjna, stanowiąca fundament jakości życia o podstawie antropocentrycznej, jest zatem jednocześnie elementarną zasadą zrównoważonego rozwoju (Borys 2005, s. 31-33).

1 NPZ 2007-2015 wśród determinant zdrowia wymienia obszary wskazane w raporcie Lalonde'a, a także określa ich procentowy udział w zdrowiu człowieka: styl życia (50\%), środowisko życia (20\%), czynniki genetyczne (20\%), działania opieki zdrowotnej (10\%). NPZ 2016-2020 potwierdza znaczenie ww. obszarów, przy czym podkreśla „postawy i zachowania składające się na styl życia” jako „najważniejsze z nich”.

2 Marc Lalonde dokonuje dekompozycji zdrowia na determinanty (pola zdrowia), umożliwiając jego operacjonalizację wskaźnikową.

Ekonomia — Wroclaw Economic Review 23/4 (2017)

(C) for this edition by CNS 
Dla autorki koncepcji zrównoważonego rozwoju zdrowie to jej podstawowy komponent, inwestycja w postęp społeczny o podłożu ekonomicznym, a tym samym oręż w walce z ubóstwem (Wysocki, Miller 2003, s. 510) — „[w] centrum zrównoważonego rozwoju są ludzie, natomiast w centrum rozwoju i dobrobytu człowieka znajduje się zdrowie"3 (Brundtland 2003, tłum. M.G.). Tym samym u podstaw zachowania zdrowia leży sytuacja społeczno-gospodarcza, a jego najpoważniejsze zagrożenie stanowią ubóstwo i niski poziom wykształcenia. Potrzebne jest zatem „podejście zintegrowane” do zdrowia, wykraczające poza „kategorie czysto medyczne" (Nasza wspólna przyszłość 1991, s. 147). Ten postulat znajduje wyraz w bezprecedensowej deklaracji działań pod tytułem Przeksztatcamy nasz świat. Agenda na Rzecz Zrównoważonego Rozwoju 2030, przyjętej przez 193 państwa ONZ w 2015 roku. Zdrowie w Agendzie 2030 zajmuje wysoką pozycję wśród 17 celów zrównoważonego rozwoju i definiowane jest w szerokim kontekście dobrostanu jako „cel 3. Dobre zdrowie i jakość życia”, pozostając w bezpośredniej relacji z celami: „1. Koniec z ubóstwem”, „2. Zero głodu” oraz „4. Dobra jakość edukacji (Ministerstwo Rozwoju 2017).

\section{Wskaźniki zrównoważonego rozwoju kraju oraz aplikacja do ich prezentacji i udostępniania}

Narzędziem mającym zastosowanie między innymi do pomiaru zdrowia w jego szerokim rozumieniu, zgodnym z ideą zrównoważonego rozwoju, to jest uwzględniającym wpływ mechanizmów społecznych, gospodarczych i środowiskowych na kondycję społeczeństwa, jest aplikacja WZR, dostępna od lutego 2016 roku na portalu informacyjnym Głównego Urzędu Statystycznego pod adresem http://wskaznikizrp.stat.gov.pl/.

Aplikacja WZR powstała w wyniku projektu „Wsparcie w zakresie rozwijania zestawu wskaźników do monitorowania narodowych strategii zrównoważonego rozwoju - Rozwój i wdrożenie polskiego zestawu wskaźników zrównoważonego rozwoju", realizowanego w okresie 1 października 2009-30 września 2011 roku w ramach umowy o dotację, zawartej między Głównym Urzędem Statystycznym a Komisją Europejską. Projekt miał na celu opracowanie i wdrożenie zestawu wskaźników do monitorowania zrównoważonego rozwoju kraju oraz strategii ich udostępniania, czyli aplikacji WZR. W rezultacie projektu z lat 2009-2011 utworzono zestaw 77 wskaźników do pomiaru zrównoważonego rozwoju kraju. Po aktualizacji zestawu WZR w 2015 roku lista mierników została poszerzona

${ }^{3}$ „People are at the center of sustainable development, and health is at the center of human development and prosperity". 
o 56 nowych miar - obecnie krajowy zestaw liczy 101 wskaźników zrównoważonego rozwoju i jest prezentowany w aplikacji $\mathrm{WZR}^{4}$.

\subsection{Budowa i metoda grupowania wskaźników zrównoważonego rozwoju kraju}

Dokonując doboru wskaźników prezentowanych w aplikacji WZR (oraz publikacji Wskaźniki zrównoważonego rozwoju Polski 2015) w ramach poszczególnych ładów, zastosowano następujące kryteria:

— obecność na liście wskaźników do monitorowania realizacji Strategii Zrównoważonego Rozwoju Unii Europejskiej,

— porównywalność międzynarodowa,

- dostępność danych,

— wiarygodność źródła danych.

Do wymogów poprawności wskaźnika zrównoważonego rozwoju zaliczono jako szczególnie istotne:

1. konieczność występowania związku merytorycznego z danym zjawiskiem zrównoważonego rozwoju poprzez odpowiedź na pytania:

— czy wskaźnik wyraża istotę zrównoważonego rozwoju?

— jaki ład, dziedzinę, jaką zasadę oraz cel zrównoważonego rozwoju wskaźnik opisuje?

2. poprawność formalną ocenianą na podstawie następujących kryteriów:

— interpretacja: dostępność wyjaśnień ułatwiających zrozumienie treści prezentowanych informacji,

— teoretyczna trafność: czy wskaźnik możliwie najlepiej odzwierciedla zachodzące zjawiska?,

— metodologia: czy istnieje jasna metodologia obliczania wskaźnika, jakość oraz porównywalność i dostępność danych? (Wskaźniki zrównoważonego rozwoju Polski 2015, s. 49).

Aplikacja WZR to publicznie dostępne narzędzie służące udostępnianiu i prezentacji wskaźników zrównoważonego rozwoju w trzech modułach: (1) krajowym (Polska, kraje członkowskie UE), (2) regionalnym (regiony, województwa) i (3) lokalnym (powiaty). Wskaźniki pogrupowano według dziedzin w ramach czterech ładów: (1) społecznego, (2) gospodarczego, (3) środowiskowego oraz (4) instytucjonalno-politycznego. Łady w zestawie WZR stanowią wzorce do osiągnięcia, przy czym układem docelowym — ,pomostem do koncepcji sustainable development" - jest ład zintegrowany, powstały w wyniku niesprzecznego, jednoczesnego tworzenia ładów: społecznego, gospodarczego i środowiskowego oraz instytucjonalno-politycznego, wyodrębnionego z ładu społecznego (Borys 2005, s. 48). U podstaw ładu zintegrowanego w zestawie WZR leży system celów stra-

${ }^{4}$ Aktualnie prowadzone są dalsze działania w celu rozbudowy krajowego zestawu wskaźników w kontekście przyjęcia „Agendy na rzecz Zrównoważonego Rozwoju 2030” w 2015 roku. 
tegicznych o charakterze społecznym, gospodarczym, środowiskowym i instytucjonalno-politycznym (zob. rysunek 1).

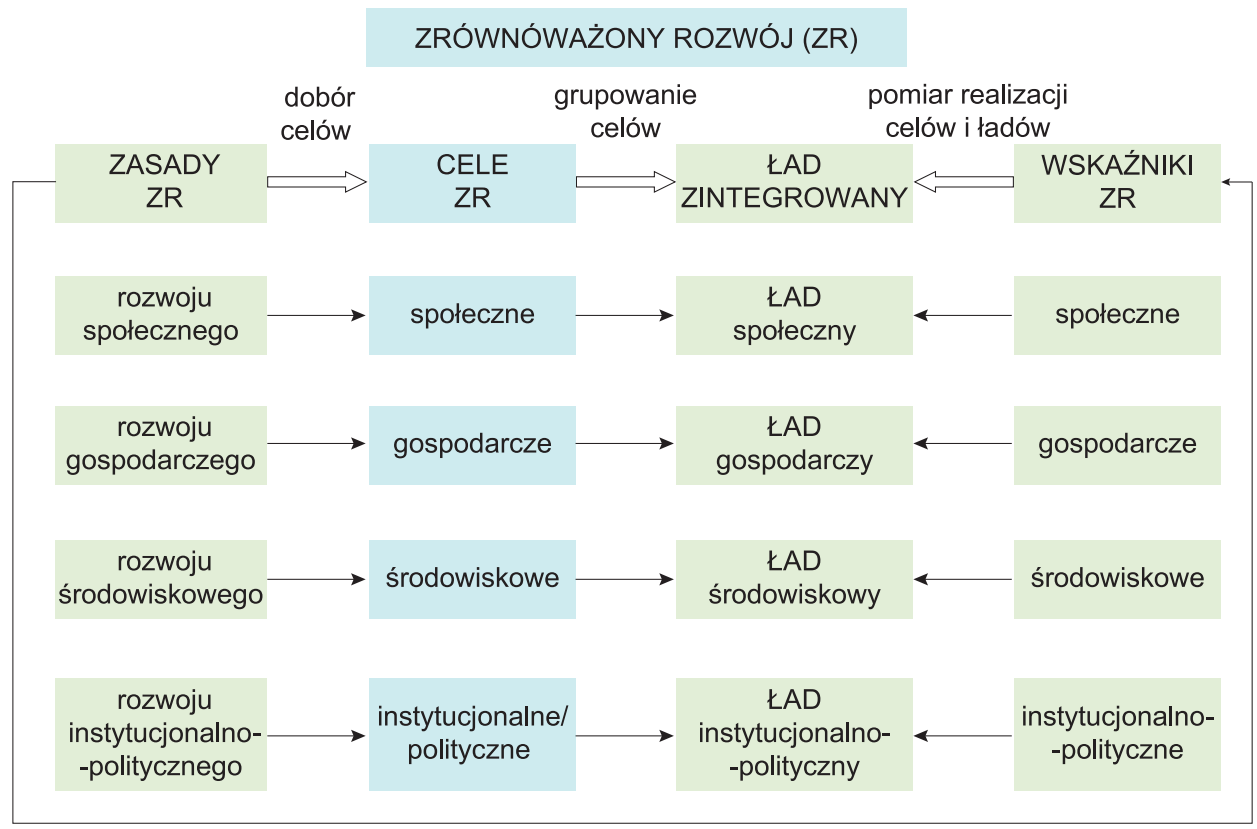

Rysunek 1. Schemat budowy i grupowania krajowych wskaźników zrównoważonego rozwoju (ZR)

Źródło: Wskaźniki zrównoważonego rozwoju Polski 2015, s. 48.

\subsection{Dobór celów zrównoważonego rozwoju kraju}

Z uwagi na brak w okresie realizacji projektu odrębnej strategii zrównoważonego rozwoju kraju doboru zestawu wskaźników zrównoważonego rozwoju Polski dokonano w oparciu o cele dotyczące wyzwań zrównoważonego rozwoju, zapisane w krajowych strategiach oraz dokumentach o charakterze strategicznym, wśród których znalazły się między innymi:

— Długookresowa Strategia Rozwoju Kraju — Polska 2030. Trzecia Fala Nowoczesności,

- Strategia Rozwoju Kraju 2020,

— Strategia Innowacyjności i Efektywności Gospodarki „Dynamiczna Polska 2020",

- Strategia Rozwoju Kapitału Ludzkiego 2020,

— Strategia Rozwoju Transportu do 2020 roku (z perspektywą do 2030 roku),

- Strategia Bezpieczeństwo Energetyczne i Środowisko - perspektywa do 2020 roku,

- Strategia Sprawne Państwo 2020, 
- Strategia Rozwoju Kapitału Społecznego 2020,

— Krajowa Strategia Rozwoju Regionalnego 2010-2020: Regiony, Miasta, Obszary Wiejskie,

- Strategia Zrównoważonego Rozwoju Wsi, Rolnictwa i Rybactwa na lata 2012-2020,

- Strategia Rozwoju Systemu Bezpieczeństwa Narodowego Rzeczypospolitej Polskiej 2022,

— Programowanie Perspektywy Finansowej 2014-2020 — Umowa Partnerstwa,

- Koncepcja Przestrzennego Zagospodarowania Kraju 2030,

— Polityka Klimatyczna Polski - Strategie Redukcji Emisji Gazów Cieplarnianych w Polsce do roku 2020,

- Polityka Energetyczna Polski do 2030 roku,

- Polityka Transportowa Państwa na lata 2006-2025,

— Polityka Leśna Państwa,

— Narodowy Program Zdrowia na lata 2007-2015 oraz 2016-2020.

\subsubsection{Jakość życia głównym celem rozwoju kraju}

Zgodnie z zapisami Strategii Długo- i Średniookresowej jakość życia oraz jej poprawa to nadrzędny cel rozwoju kraju, a także punkt wyjścia do formułowania bardziej szczegółowych koncepcji rozwoju w wymiarze społecznym, gospodarczym i środowiskowym, włączając zdrowie publiczne ${ }^{5}$. Potwierdzenie wielowymiarowej natury zdrowia oraz jego znaczenia dla poprawy jakości życia, leżącej u podstaw zrównoważonego rozwoju kraju, stanowi następujący zapis Strategii Rozwoju Kapitału Ludzkiego 2020:

Cel szcze gółow y 4. Poprawa zdrowia obywateli oraz efektywności systemu opieki zdrowotnej. Czwarty c el strategii odnosi się do „szeroko rozumianego zdrowia społeczeństwa” [...]. W SRKL pozostawanie w zdrowiu jest nie tylko podstawowym warunkiem utrzymania aktywności społecznej, obywatelskiej i ekonomicznej, ale jest także jednym z kluczowych wymiarów dobrej jakości życia. A jakość życia, w tym jego wymiar zdrowotny, to cel nadrzędny, któremu podporządkowane są wszystkie programy o charakterze strategicznym [wyróżnienia - M.G.]. (Strategia Rozwoju Kapitału Ludzkiego 2020, 2013, s. $40-41)$

Wśród priorytetów poprawy zdrowia SRKL wymienia zatem:

— dostosowanie systemu opieki zdrowotnej do nowej sytuacji demograficznej;

- upowszechnienie i wzmocnienie działań profilaktycznych opartych na dowodach naukowych;

— masową popularyzację kultury bezpieczeństwa i zdrowego stylu życia;

— poprawę efektywności systemu opieki zdrowotnej.

5 Cel główny Długookresowej Strategii Rozwoju Kraju to „Poprawa jakości życia Polaków”, realizowany poprzez Średniookresową Strategię Rozwoju Kraju oraz w oparciu o dziewięć strategii zintegrowanych.

Ekonomia - Wroclaw Economic Review 23/4 (2017)

(C) for this edition by CNS 
Do tak „szeroko rozumianego zdrowia społeczeństwa” zarówno w skali kraju (na przykład SRKL), jak i globu (Agenda 2030) odnoszą się dziedziny ładu społecznego w krajowym zestawie wskaźników zrównoważonego rozwoju:

- zmiany demograficzne,

— zdrowie publiczne,

- ubóstwo i warunki życia,

- edukacja,

— dostęp do rynku pracy,

— bezpieczeństwo publiczne,

— wzorce konsumpcji.

Realizację priorytetów „szeroko rozumianego zdrowia” w ramach wymienionych dziedzin monitorują przyporządkowane im odpowiednie wskaźniki zrównoważonego rozwoju kraju, dostępne w aplikacji WZR oraz publikacji Wskaźniki zrównoważonego rozwoju Polski 2015. W tabeli 1 przedstawiono mierniki zrównoważonego rozwoju kraju do monitorowania poszczególnych dziedzin ładu społecznego, warunkujących jakość życia społeczeństwa.

\section{Wskaźniki zrównoważonego rozwoju kraju do pomiaru ładu społecznego}

Tabela 1. Wskaźniki zrównoważonego rozwoju kraju w ramach dziedzin ładu społecznego

\begin{tabular}{|c|c|}
\hline \multicolumn{2}{|r|}{ Lad społeczny } \\
\hline Dziedzina & Wskaźnik \\
\hline $\begin{array}{l}\text { Zmiany } \\
\text { demograficzne }\end{array}$ & $\begin{array}{l}\text { — współczynnik dzietności } \\
\text { — wskaźnik migracji zagranicznych } \\
\text { - ludność w wieku poprodukcyjnym na } 100 \text { osób w wieku produkcyjnym } \\
\quad(\text { NOWY!6) } \\
\text { — stopa przyrostu/ubytku rzeczywistego ludności (NOWY!) }\end{array}$ \\
\hline $\begin{array}{l}\text { Zdrowie } \\
\text { publiczne }\end{array}$ & $\begin{array}{l}\text { — oczekiwane trwanie życia osób w wieku } 65 \text { lat w zdrowiu } \\
\text { — standaryzowane współczynniki umieralności z powodu chorób układu } \\
\text { krążenia, nowotworów złośliwych oraz przewlekłych chorób dolnych } \\
\text { dróg oddechowych i cukrzycy } \\
\text { — Europejski Konsumencki Indeks Zdrowia EHCI } \\
\text { — narażenie ludności miejskiej na ponadnormatywne oddziaływanie pyłu } \\
\text { PM }{ }_{10} \text { (NOWY!) } \\
\text { — narażenie ludności miejskiej na powietrze zanieczyszczone ozonem } \\
\text { (NOWY!) }\end{array}$ \\
\hline
\end{tabular}

${ }^{6}$ Nowy miernik wprowadzony do krajowego zestawu wskaźników zrównoważonego rozwoju w wyniku prac aktualizacyjnych w 2015 roku.

Ekonomia — Wroclaw Economic Review 23/4 (2017)

(C) for this edition by CNS 


\begin{tabular}{|c|c|}
\hline \multicolumn{2}{|r|}{ Lad społeczny } \\
\hline Dziedzina & Wskaźnik \\
\hline $\begin{array}{l}\text { Ubóstwo } \\
\text { i warunki życia }\end{array}$ & $\begin{array}{l}\text { — zagrożenie ubóstwem trwałym } \\
\text { — wskaźnik zagrożenia ubóstwem lub wykluczeniem społecznym } \\
\text { — nierówność rozkładu dochodów } \\
\text { — zadłużenie gospodarstw domowych } \\
\text { — przeciętny miesięczny dochód do dyspozycji na } 1 \text { osobę w gospodarstwie } \\
\text { domowym (NOWY!) } \\
\text { - liczba mieszkań oddanych do użytkowania na } 1000 \text { ludności w wieku } \\
\text { 25-34 lata (NOWY!) }\end{array}$ \\
\hline Edukacja & $\begin{array}{l}\text { - osoby dorosłe uczestniczące w kształceniu i szkoleniu } \\
\text { — odsetek dzieci na wsi w wieku 3-4 lata objętych wychowaniem przed- } \\
\text { szkolnym } \\
\text { — wydatki publiczne na edukację w relacji do PKB } \\
\text { — odsetek osób w wieku 25-64 lata z wykształceniem co najwyżej gimna- } \\
\text { zjalnym (NOWY!) } \\
\text { — młodzież niekontynuująca nauki (NOWY!) }\end{array}$ \\
\hline $\begin{array}{l}\text { Dostęp do rynku } \\
\text { pracy }\end{array}$ & $\begin{array}{l}\text { — odsetek osób w gospodarstwach domowych bez osób pracujących } \\
\text { — stopa bezrobocia długotrwałego } \\
\text { — stopa bezrobocia według BAEL } \\
\text { — wskaźnik zatrudnienia osób niepełnosprawnych } \\
\text { — zróżnicowanie wynagrodzeń ze względu na płeć } \\
\text { — wskaźnik zatrudnienia kobiet z najmłodszym dzieckiem w wieku do } 5 \text { lat } \\
\quad \text { (NOWY!) }\end{array}$ \\
\hline $\begin{array}{l}\text { Bezpieczeństwo } \\
\text { publiczne }\end{array}$ & $\begin{array}{l}\text { — ofiary śmiertelne wypadków drogowych na } 1 \text { mln ludności } \\
\text { — przestępstwa stwierdzone na } 1000 \text { mieszkańców (NOWY!) }\end{array}$ \\
\hline $\begin{array}{l}\text { Wzorce } \\
\text { konsumpcji }\end{array}$ & $\begin{array}{l}\text { — zużycie energii elektrycznej w gospodarstwach domowych na } 1 \text { miesz- } \\
\text { kańca } \\
\text { — struktura przeciętnych miesięcznych wydatków na } 1 \text { osobę w gospodar- } \\
\text { stwach domowych według rodzajów (NOWY!) } \\
\text { — struktura samochodów osobowych według grup wieku (NOWY!) }\end{array}$ \\
\hline
\end{tabular}

Źródło: Wskaźniki zrównoważonego rozwoju Polski 2015, s. 54.

\subsection{Monitorowanie zdrowia publicznego}

Cele zrównoważonego rozwoju odnoszące się do dziedziny „zdrowie publiczne”, która stanowi przedmiot analizy drugiej części tego artykułu, zostały wyłonione z Długookresowej Strategii Rozwoju Kraju — Polska 2030. Trzecia Fala Nowoczesności (DSRK), Strategii Rozwoju Kapitału Ludzkiego 2020 (SRKL), Strategii Bezpieczeństwo Energetyczne i Środowisko — perspektywa do 2020 roku (BEiŚ) oraz Narodowego Programu Zdrowia na lata 2016-2020 (NPZ). Wszystkie z wymienionych dokumentów wpisują się w priorytet ogólnej poprawy jakości życia obywateli poprzez odniesienie do stabilnego wzrostu gospodarczego (DSRK), podnoszenia poziomu kompetencji i kwalifikacji (SRKL), ochrony środowiska 
i zielonego wzrostu (BEiŚ) oraz wydłużenia życia w zdrowiu (NPZ). Reasumując, trzeba stwierdzić, że szeroki kontekst zdrowia publicznego w krajowym zestawie WZR świadczy o zintegrowanym, pozamedycznym podejściu do dziedziny, zgodnym z ideą zrównoważonego rozwoju (Nasza wspólna przyszłość 1991, s. 147).

Podstawowym miernikiem w krajowym zestawie WZR służącym do oceny jakości życia społeczeństwa jest „oczekiwane trwanie życia osób w wieku 65 lat w zdrowiu". Wskaźnik ten określa liczbę lat, które osoba od 65. roku życia jest w stanie przeżyć w dobrym zdrowiu, rozumianym jako brak choroby oraz niepełnosprawności. Miernik obliczany jest w oparciu o dane pochodzące z Europejskiego Badania Dochodów i Warunków Życia (EU-SILC - European Union Statistics on Income and Living Conditions). „Oczekiwane trwanie życia osób w wieku 65 lat w zdrowiu” prezentuje dwie cechy populacji: długość życia i zdrowie. Tym samym miernik uzupełnia prognozowaną liczbę lat życia informacją o jego jakości.

W 2014 roku oczekiwana długość życia w zdrowiu Polaków w wieku 65 lat wyniosła 7,5 roku i była krótsza o 0,6 roku od przewidywanej długości życia w zdrowiu sześćdziesięciopięcioletnich Polek ( $8,1 \mathrm{roku})$. Wartości te były niższe od średniej UE, która zarówno dla mężczyzn (tabela 2), jak i kobiet (tabela 3) wyniosła w badanym okresie 8,6 roku. Dla porównania - maksymalna wartość miernika w 2014 roku na terenie UE była równa 15,2 roku w przypadku mężczyzn (Szwedzi), natomiast w przypadku kobiet (Szwedki) - 16,7 lat.

Tabela 2. Oczekiwane trwanie życia osób w wieku 65 lat w zdrowiu. Mężczyźni (lata)

\begin{tabular}{c|c|c|c|c}
\hline Lata & UE & Polska & Maks. UE & Min. UE \\
\hline 2004 & - & - & 13,3 & 4,6 \\
\hline 2005 & - & 8,4 & 13,2 & 3,4 \\
\hline 2006 & - & 7,3 & 13,0 & 4,0 \\
\hline 2007 & - & 6,5 & 13,1 & 3,6 \\
\hline 2008 & - & 7,0 & 13,1 & 3,0 \\
\hline 2009 & - & 6,9 & 13,6 & 3,5 \\
\hline 2010 & 8,7 & 6,7 & 12,3 & 3,3 \\
\hline 2011 & 8,5 & 7,6 & 12,4 & 3,5 \\
\hline 2012 & 8,5 & 7,4 & 12,5 & 3,5 \\
\hline 2013 & 8,5 & 7,2 & 12,9 & 4,0 \\
\hline 2014 & 8,6 & 7,5 & 15,2 & 4,0 \\
\hline
\end{tabular}

Źródło: Eurostat.

${ }^{7}$ W odróżnieniu od wskaźnika oczekiwanej długości życia, który określa jedynie długość życia.

Ekonomia - Wroclaw Economic Review 23/4 (2017)

(C) for this edition by CNS 


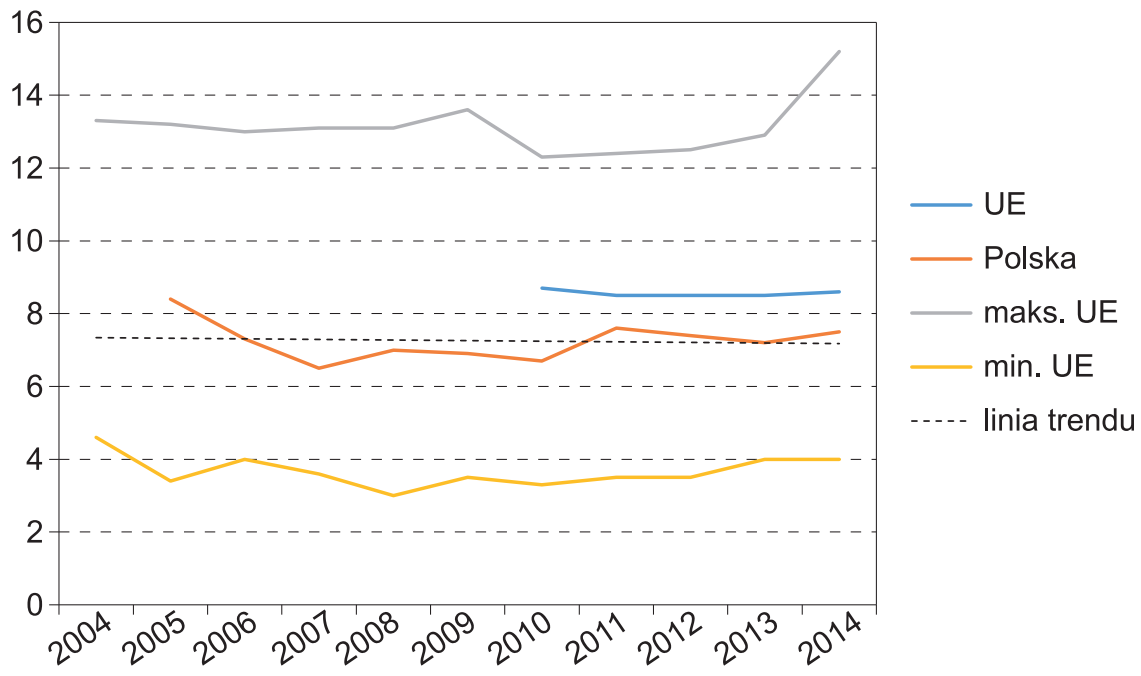

Rysunek 2. Oczekiwane trwanie życia osób w wieku 65 lat w zdrowiu. Mężczyźni (lata) Źródło: Eurostat.

Linia trendu oczekiwanego trwania życia Polaków w wieku 65 lat w zdrowiu utrzymuje się od dekady na stałym poziomie, to jest poniżej 8 lat (zob. rysunek 2). Największe odchylenia od trendu zaobserwowano w 2005 roku (wartość maksymalna: 8,4 roku) oraz w 2007 roku (wartość minimalna: 6,5 roku). W wypadku Polek oczekiwane trwanie życia w zdrowiu wykazuje tendencję spadkową w ostatniej dekadzie (zob. rysunek 3). Największe odchylenia od trendu wśród kobiet wystąiły w 2005 roku (wartość maksymalna: 10,2 roku) oraz 2007 roku (wartość minimalna: 7,1 roku), podobnie jak w przypadku mężczyzn.

Tabela 3. Oczekiwane trwanie życia osób w wieku 65 lat w zdrowiu. Kobiety (lata)

\begin{tabular}{c|c|c|c|c}
\hline Lata & UE & Polska & Maks. UE & Min. UE \\
\hline 2004 & - & - & 13,5 & 3,8 \\
\hline 2005 & - & 10,2 & 14,0 & 3,6 \\
\hline 2006 & - & 8,2 & 14,2 & 3,8 \\
\hline 2007 & - & 7,1 & 14,3 & 4,2 \\
\hline 2008 & - & 7,7 & 14,0 & 2,7 \\
\hline 2009 & - & 7,7 & 14,7 & 2,9 \\
\hline 2010 & 8,8 & 7,5 & 13,7 & 2,8 \\
\hline 2011 & 8,6 & 8,3 & 13,2 & 2,9 \\
\hline 2012 & 8,5 & 7,8 & 12,9 & 3,1 \\
\hline 2013 & 8,6 & 7,8 & 13,8 & 3,7 \\
\hline 2014 & 8,6 & 8,1 & 16,7 & 3,6 \\
\hline
\end{tabular}

Źródło: Eurostat. 


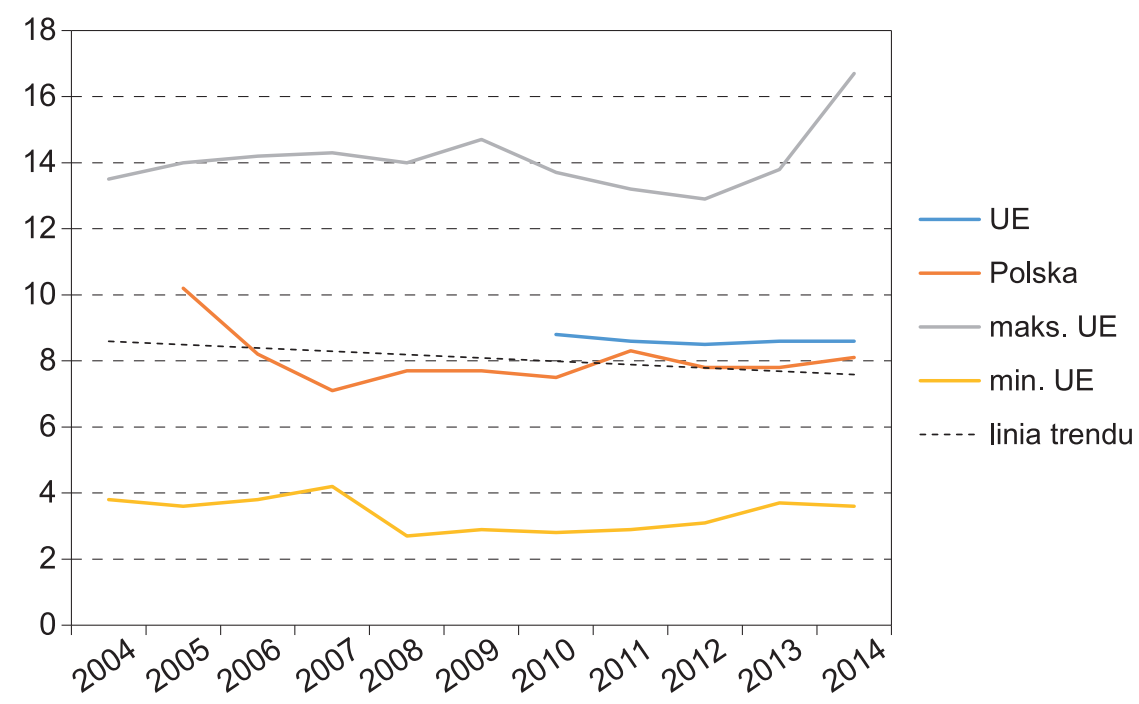

Rysunek 3. Oczekiwane trwanie życia osób w wieku 65 lat w zdrowiu. Kobiety (lata)

Źródło: Eurostat.

Miarą o charakterze negatywnym służącą do oceny stanu zdrowia publicznego w krajowym zestawie WZR są, ,standaryzowane współczynniki umieralności z powodu chorób układu krążenia, nowotworów złośliwych oraz przewlekłych chorób dolnych dróg oddechowych i cukrzycy". Wskaźnik obliczany jest jako średnia ważona surowych współczynników umieralności dla poszczególnych grup wieku w przeliczeniu na 100 tys. ludności populacji standardowej ${ }^{8}$. Jednostki chorobowe ujęte $\mathrm{w}$ definicji miernika należą do chorób cywilizacyjnych — istotnej przyczyny przedwczesnej umieralności, inwalidztwa, hospitalizacji oraz absencji w miejscu pracy. Poza zagrożeniem dla zdrowia i życia współczynnik informuje o efektywności profilaktyki i skuteczności leczenia.

Do chorób cywilizacyjnych stanowiących najczęstszą przyczynę umieralności Polaków należą choroby układu krążenia. W 2014 roku standaryzowane współczynniki umieralności z ich powodu były przyczyną około 591 zgonów w przeliczeniu na 100 tys. populacji standardowej Polski, czyli o 217 zgonów więcej niż w UE (zob. tabela 4). WHO.

${ }^{8}$ Za standard przyjmuje się rozkład populacji europejskiej określony w oparciu o wytyczne 
Tabela 4. Standaryzowane współczynniki umieralności z powodu chorób układu krążenia

\begin{tabular}{c|c|c|c|c}
\hline Lata $^{9}$ & UE & Polska & Maks. UE & Min. UE \\
\hline 2011 & 395,3 & 638,9 & 1181,5 & 223,0 \\
\hline 2012 & 394,3 & 652,4 & 1168,0 & 221,6 \\
\hline 2013 & 383,4 & 635,3 & 1085,8 & 212,9 \\
\hline 2014 & 373,6 & 591,4 & 1131,0 & 202,9 \\
\hline
\end{tabular}

Źródło: Eurostat.

W badanym okresie (2011-2014) można zaobserwować lekką tendencję spadkową miernika (zob. rysunek 4). W roku 2014 jego wartość była najniższa od czterech lat; w porównaniu z rekordowym 2012 rokiem (652 zgony) liczba zgonów z powodu chorób układu krążenia spadła wówczas o 61.

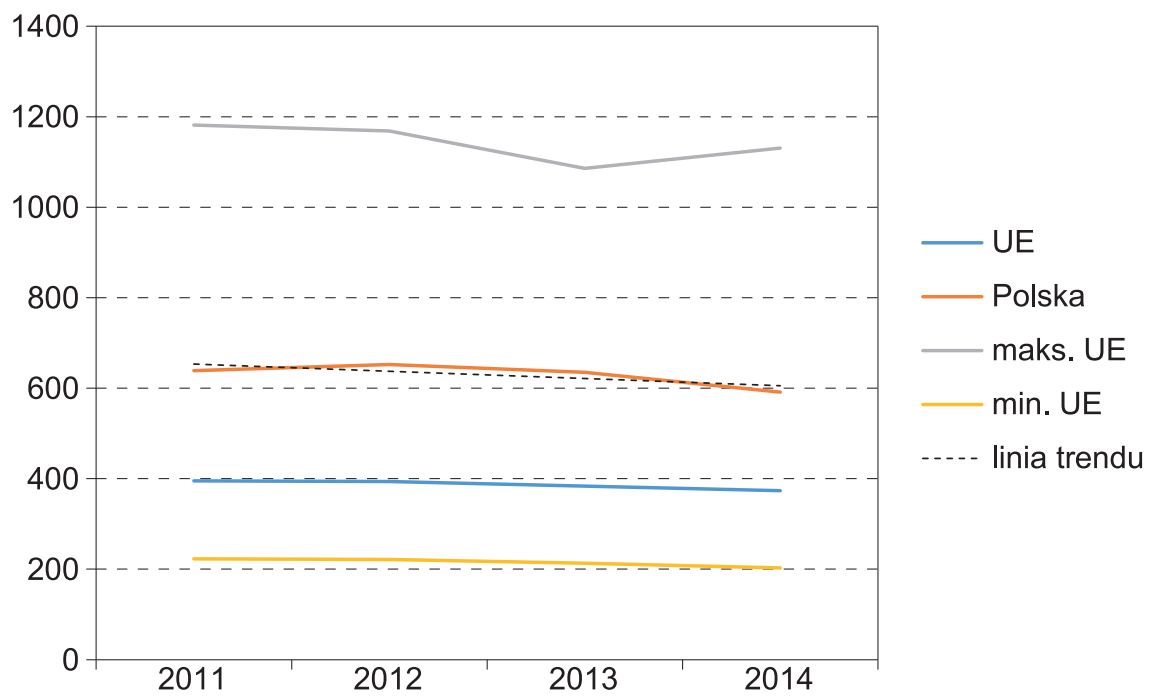

Rysunek 4. Standaryzowane współczynniki umieralności z powodu chorób układu krążenia

Źródło: Eurostat.

Wśród chorób cywilizacyjnych drugą najczęstszą przyczyną zgonów Polaków są nowotwory złośliwe. W 2014 roku standaryzowany współczynnik umieralności z powodu nowotworów złośliwych wyniósł ponad 292 zgony w przeliczeniu na 100 tys. ludności populacji standardowej Polski, to jest o blisko 30 więcej w relacji do średniej UE (zob. tabela 5).

${ }^{9}$ Dane w tabeli obejmują wyłącznie lata 2011-2014, ponieważ są one nieporównywalne z wartościami dla lat wcześniejszych (2004-2010), co ma związek ze zmianami grupowania przyczyn zgonów wprowadzonymi w 2011 roku. Przyczyny zgonów są aktualnie grupowane według bardziej szczegółowego wykazu, obejmującego 86 przyczyn zgonów w miejsce wcześniejszych 65 .

Ekonomia — Wroclaw Economic Review 23/4 (2017)

(C) for this edition by CNS 
Tabela 5. Standaryzowane współczynniki umieralności z powodu nowotworów złośliwych

\begin{tabular}{c|c|c|c|c}
\hline Lata & UE & Polska & Maks. UE & Min. UE \\
\hline 2011 & 268,6 & 297,4 & 357,3 & 195,8 \\
\hline 2012 & 267,3 & 300,0 & 361,1 & 205,6 \\
\hline 2013 & 265,1 & 292,4 & 352,1 & 202,3 \\
\hline 2014 & 261,5 & 292,3 & 348,1 & 201,0 \\
\hline
\end{tabular}

Źródło: Eurostat.

W ciągu ostatnich czterech lat najwyższą wartość współczynnika zaobserwowano w 2012 roku (300 zgonów), czyli o prawie 8 więcej od wartości minimalnej, odnotowanej w roku 2014. Różnica między poziomem miernika w Polsce a UE nie pogłębia się, choć równocześnie nie maleje. Podczas gdy przeciętne wartości standaryzowanego współczynnika umieralności z powodu nowotworów złośliwych wykazują tendencję spadkową w UE, wartości miernika w Polsce utrzymują się na względnie stałym poziomie (zob. rysunek 5).

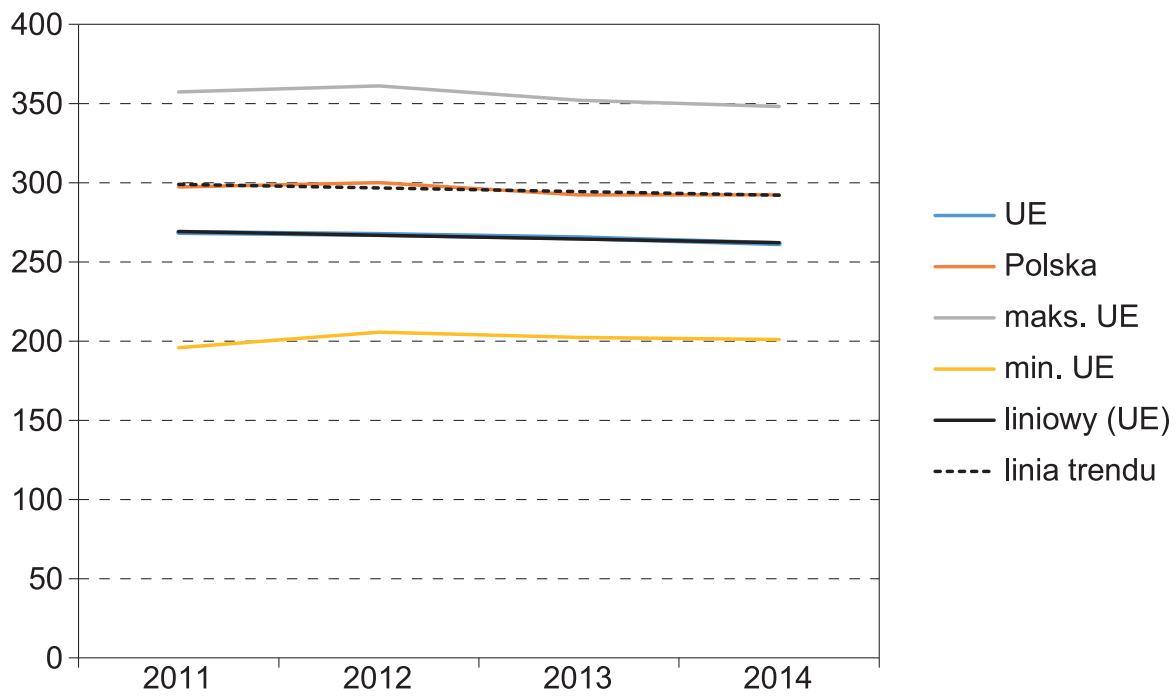

Rysunek 5. Standaryzowane współczynniki umieralności z powodu nowotworów złośliwych Źródło: Eurostat.

Wartości standaryzowanego współczynnika umieralności z powodu przewlekłych chorób dolnych dróg oddechowych na terenie naszego kraju w latach 2011-2014 odchylały się od średniej UE, tym razem na korzyść Polaków. W 2014 roku liczba standaryzowanych zgonów z powodu przewlekłych chorób dolnych dróg oddechowych wyniosła w Polsce 21, czyli o 12 mniej w relacji do średniej UE (zob. tabela 6). 
Tabela 6. Standaryzowane współczynniki umieralności z powodu przewlekłych chorób dolnych dróg oddechowych

\begin{tabular}{c|c|c|c|c}
\hline Lata & UE & Polska & Maks. UE & Min. UE \\
\hline 2011 & 34,0 & 26,5 & 73,9 & 15,1 \\
\hline 2012 & 34,9 & 24,7 & 73,1 & 15,6 \\
\hline 2013 & 34,9 & 25,8 & 73,4 & 16,0 \\
\hline 2014 & 33,1 & 21,0 & 69,0 & 14,3 \\
\hline
\end{tabular}

Źródło: Eurostat.

Ponadto współczynnik wykazywał tendencję spadkową w badanym okresie, zmniejszając dystans do minimum UE (zob. rysunek 6).

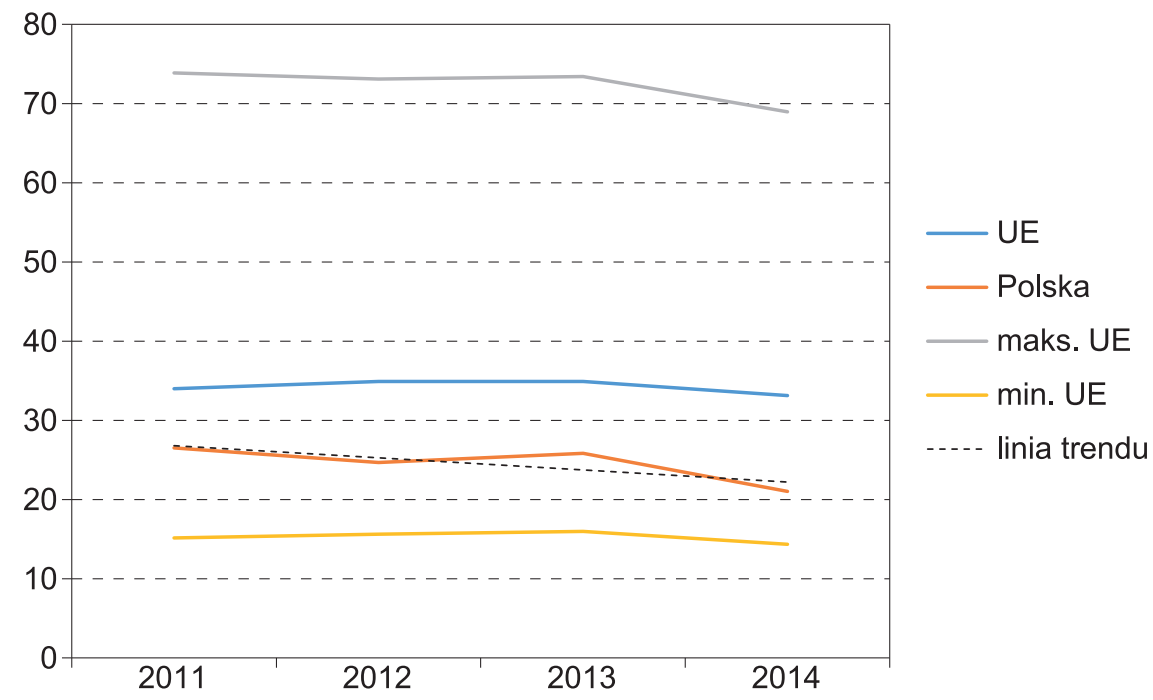

Rysunek 6. Standaryzowane współczynniki umieralności z powodu przewlekłych chorób dolnych dróg oddechowych

Źródło: Eurostat.

Standaryzowany współczynnik umieralności z powodu cukrzycy oscyluje w Polsce wokół średniej UE (w przedziale 22-25 zgonów), choć w latach 2011-2014 zawsze odchylał się od unijnego poziomu (zob. rysunek 7) - najmniej w 2014 roku, to jest o 0,3 (zob. tabela 7). 
Tabela 7. Standaryzowane współczynniki umieralności z powodu cukrzycy

\begin{tabular}{c|c|c|c|c}
\hline Lata & UE & Polska & Maks. UE & Min. UE \\
\hline 2011 & 23,0 & 23,6 & 73,5 & 9,5 \\
\hline 2012 & 23,1 & 24,6 & 70,8 & 9,5 \\
\hline 2013 & 22,8 & 24,9 & 69,7 & 9,1 \\
\hline 2014 & 22,0 & 22,3 & 72,4 & 9,2 \\
\hline
\end{tabular}

Źródło: Eurostat.

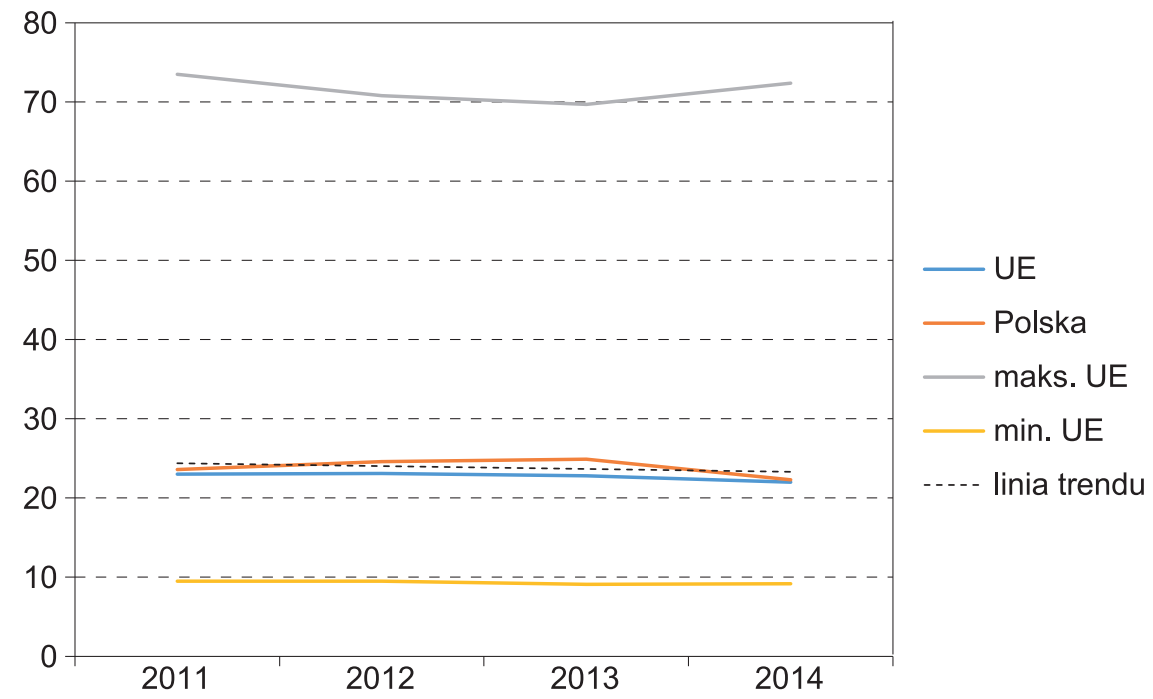

Rysunek 7. Standaryzowane współczynniki umieralności z powodu cukrzycy

Źródło: Eurostat.

„Europejski Konsumencki Indeks Zdrowia EHCI” to miernik w krajowym zestawie WZR pozwalający na ocenę jakości opieki zdrowotnej. Indeks opiera się na 48 wskaźnikach monitorujących sześć obszarów zdrowia: (1) prawa pacjenta, (2) czas oczekiwania na leczenie, (3) skuteczność leczenia, (4) zakres i zasięg świadczonych usług, (5) farmaceutyki i (6) profilaktykę.

Tabela 8. Europejski Konsumencki Indeks Zdrowia EHCI

\begin{tabular}{c|c|c|c|c}
\hline Lata & Liczba punktów możliwych do uzyskania & Polska & Maks. UE & Min. UE \\
\hline 2006 & 750 & 409 & 576 & 340 \\
\hline 2007 & 1000 & 447 & 806 & 435 \\
\hline 2008 & 1000 & 511 & 839 & 449 \\
\hline 2009 & 1000 & 565 & 863 & 448 \\
\hline 2010 & - & - & - & - \\
\hline 2011 & - & - & - & - \\
\hline
\end{tabular}




\begin{tabular}{c|c|c|c|c}
\hline Lata & Liczba punktów możliwych do uzyskania & Polska & Maks. UE & Min. UE \\
\hline 2012 & 1000 & 577 & 872 & 456 \\
\hline 2013 & 1000 & 521 & 870 & 478 \\
\hline 2014 & 1000 & 511 & 898 & 453 \\
\hline 2015 & 1000 & 523 & 916 & 523 \\
\hline 2016 & 1000 & 564 & 927 & 497 \\
\hline
\end{tabular}

Źródło: Health Consumer Powerhouse.

Maksymalna liczba punktów do zdobycia w rankingu EHCI wynosi $1000^{10}$. W latach 2006-2016 wartości Europejskiego Konsumenckiego Indeksu Zdrowia w Polsce były zbliżone do minimum UE (zob. rysunek 8). Co więcej, liczba punktów uzyskana przez Polskę w 2015 roku (523) była wartością minimalną w UE w badanym okresie (zob. tabela 8). Polska opieka medyczna otrzymała wówczas szczególnie niskie noty w takich obszarach, jak: e-zdrowie, czas oczekiwania na leczenie (zabieg chirurgiczny, terapia nowotworowa), długoterminowa opieka geriatryczna i dostęp do leków nowej generacji (Euro Health Consumer Index 2015 Report 2015, s. 21-23).

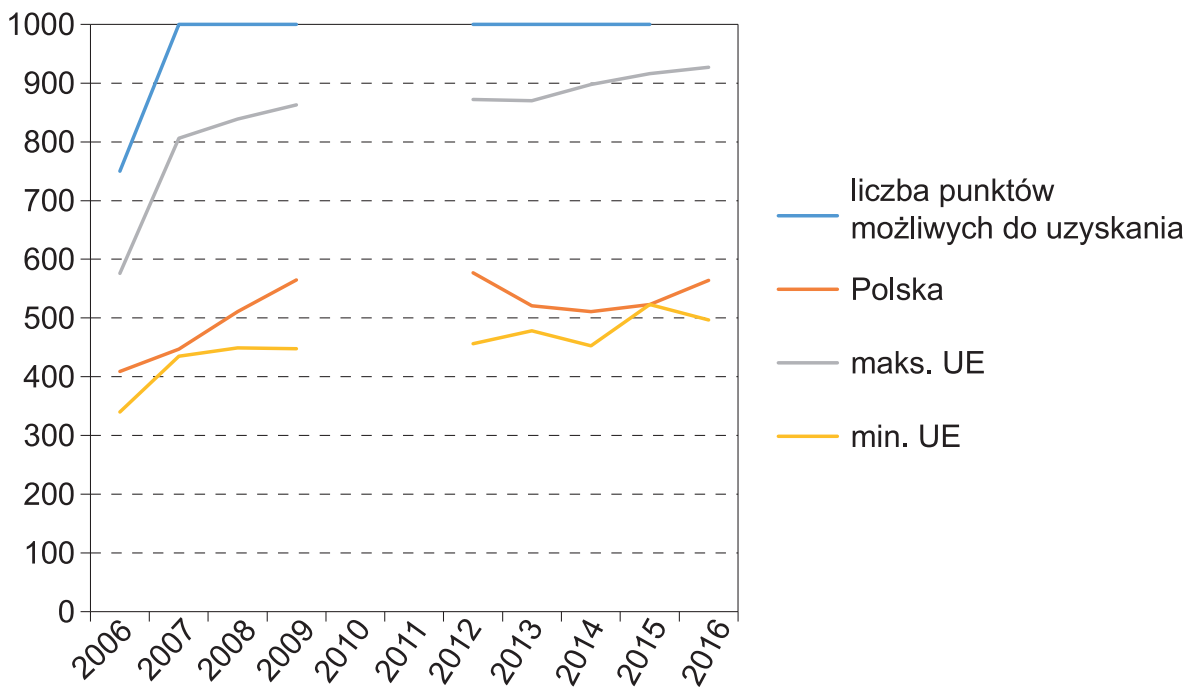

Rysunek 8. Europejski Konsumencki Indeks Zdrowia EHCI

Źródło: Health Consumer Powerhouse.

Miernikami dziedziny „zdrowie publiczne” w krajowym zestawie WZR prezentującymi wpływ środowiska fizycznego na kondycję społeczeństwa są wskaźniki jakości powietrza. Pierwszy z nich: „narażenie ludności miejskiej na ponadnormatywne oddziaływanie pyłu $\mathrm{PM}_{10}$ " informuje ósed-

10 W 2006 roku maksymalna liczba punktów do zdobycia w rankingu EHCI wynosiła 750.

Ekonomia — Wroclaw Economic Review 23/4 (2017)

(C) for this edition by CNS 
niorocznym ważonym stężeniu pyłu $\mathrm{PM}_{10}$ na stacjach tła miejskiego w aglomeracjach. Cząstki pyłu drobnego $\left(\mathrm{PM}_{10}\right) \mathrm{i}$ bardzo drobnego $\left(\mathrm{PM}_{2,5}\right)$ pochodzą $\mathrm{z}$ tak zwanej niskiej emisji, głównie ze źródeł komunalnych i sektora transportowego. Powodują schorzenia układu krążenia i dróg oddechowych.

Tabela 9. Narażenie ludności miejskiej na ponadnormatywne oddziaływanie $\mathrm{PM}_{10}\left(\mu \mathrm{g} / \mathrm{m}^{3}\right)$

\begin{tabular}{c|c|c|c|c}
\hline Lata & UE & Polska & Maks. UE & Min. UE \\
\hline 2004 & 26,9 & 34,0 & 54,0 & 13,5 \\
\hline 2005 & 28,4 & 37,1 & 49,7 & 14,8 \\
\hline 2006 & 30,2 & 42,6 & 54,9 & 15,7 \\
\hline 2007 & 28,5 & 32,3 & 57,5 & 14,7 \\
\hline 2008 & 26,3 & 31,5 & 61,0 & 11,1 \\
\hline 2009 & 26,1 & 34,9 & 54,5 & 13,1 \\
\hline 2010 & 25,8 & 38,2 & 48,6 & 12,1 \\
\hline 2011 & 27,0 & 39,3 & 57,8 & 12,5 \\
\hline 2012 & 24,7 & 37,3 & 46,1 & 11,1 \\
\hline 2013 & 23,8 & 33,1 & 43,9 & 12,0 \\
\hline 2014 & 22,5 & 35,2 & 41,2 & 13,7 \\
\hline
\end{tabular}

Źródło: Eurostat.

$\mathrm{Z}$ analizy danych Eurostatu wynika, że średnioroczne stężenie pyłu $\mathrm{PM}_{10}$ w Polsce utrzymuje się na poziomie wyższym od średniej UE. W ostatniej dekadzie wartości miernika wykazywały się dużą amplitudą zmian (zob. rysunek 9). W okresie dwóch lat (2004 i 2006) średnioroczne stężenie pyłu PM $_{10}$ osiągnęło odpowiednio lokalne minimum $\left(34 \mu \mathrm{g} / \mathrm{m}^{3}\right)$ i maksimum $\left(42,6 \mu \mathrm{g} / \mathrm{m}^{3}\right)$ - był to jedyny przypadek przekroczenia dopuszczalnego poziomu średniorocznego stężenia $\mathrm{PM}_{10}{ }^{11}$ na obszarze Polski w latach 2004-2014.

„Narażenie ludności miejskiej na powietrze zanieczyszczone ozonem" jest ostatnim miernikiem monitorującym zdrowie publiczne w krajowym zestawie WZR. Wskaźnik pokazuje roczną sumę średnich ośmiogodzinnych stężeń dziennych ozonu, przekraczających dopuszczalną wartość $70 \mu \mathrm{g} / \mathrm{m}^{3}$. Ozon troposferyczny jest zanieczyszczeniem wtórnym, powstaje w wyniku reakcji fotochemicznych tlenków azotu i lotnych związków organicznych w atmosferze (przyspiesza je wysoka temperatura powietrza). Przyczynia się nie tylko do chorób serca i dróg oddechowych, ale ma także negatywny wpływ na roślinność oraz powoduje korozję materiałów.

11 Dyrektywa Parlamentu Europejskiego i Rady 2008/50/WE z dnia 21 maja 2008 roku w sprawie jakości powietrza i czystszego powietrza dla Europy określa dopuszczalny próg dla średniorocznego stężenia $\mathrm{PM}_{10}$ na poziomie $40 \mu \mathrm{g} / \mathrm{m}^{3}$. 


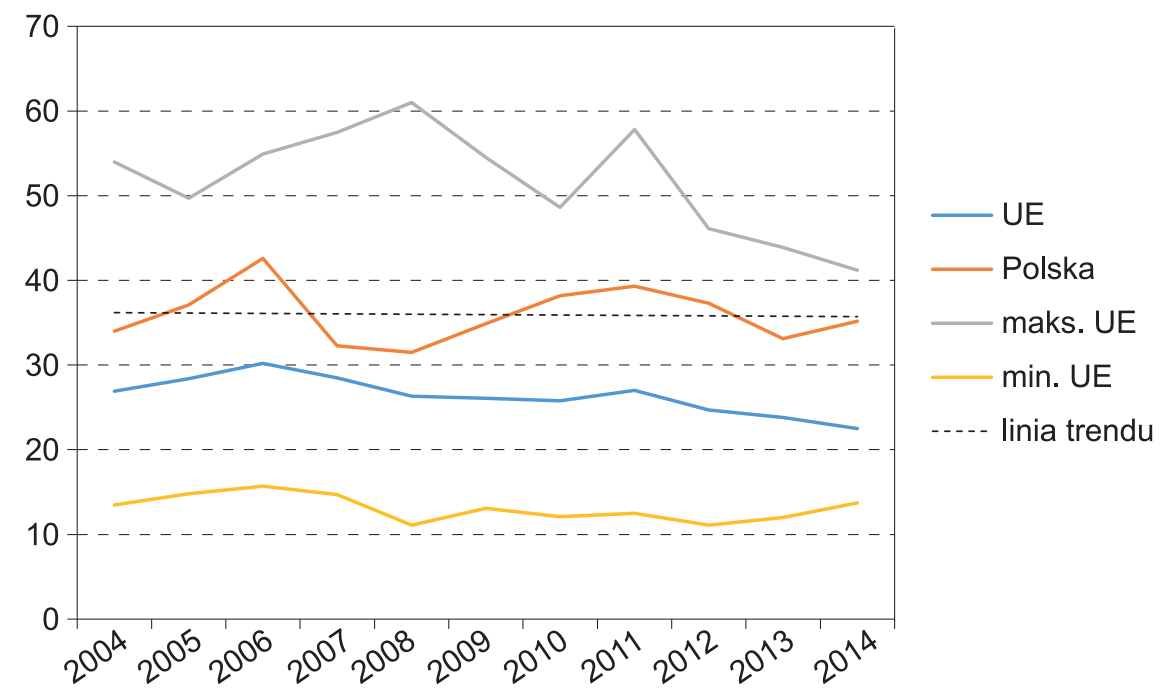

Rysunek 9. Narażenie ludności miejskiej na ponadnormatywne oddziaływanie $\mathrm{PM}_{10}$ Źródło: Eurostat.

Tabela 10. Narażenie ludności miejskiej na powietrze zanieczyszczone ozonem $\left(\mu \mathrm{g} / \mathrm{m}^{3}\right)$

\begin{tabular}{c|c|c|c|c}
\hline Lata & UE & Polska & Maks. UE & Min. UE \\
\hline 2004 & 3506 & 2799 & 9141 & 353 \\
\hline 2005 & 3669 & 3957 & 9292 & 308 \\
\hline 2006 & 4548 & 4553 & 9012 & 882 \\
\hline 2007 & 3648 & 3612 & 9327 & 0 \\
\hline 2008 & 3609 & 3507 & 11051 & 175 \\
\hline 2009 & 3698 & 3257 & 10603 & 307 \\
\hline 2010 & 3432 & 2866 & 9634 & 839 \\
\hline 2011 & 3749 & 3411 & 10137 & 703 \\
\hline 2012 & 3530 & 3598 & 10142 & 930 \\
\hline 2013 & 3373 & 3062 & 5760 & 574 \\
\hline 2014 & 3243 & 3028 & 7201 & 0 \\
\hline
\end{tabular}

Źródło: Eurostat.

Podobnie jak stężenie $\mathrm{PM}_{10}$, stężenie ozonu $\mathrm{w}$ dolnej warstwie atmosfery odznaczało się silnymi wahaniami w latach 2004-2014 na terenie Polski (zob. rysunek 10). W 2004 roku miernik osiągnął wartość minimalną $\left(2799 \mu \mathrm{g} / \mathrm{m}^{3}\right)$, by za dwa lata dojść do maksimum - $4553 \mu \mathrm{g} / \mathrm{m}^{3}$ (zob. tabela 10). W ostatniej dekadzie stężenie ozonu na obszarze Polski trzykrotnie przekroczyło średnią UE. Natomiast w 2014 roku wartość miernika była niższa od przeciętnej wartości 
w UE o $215 \mu \mathrm{g} / \mathrm{m}^{3}$ i wyniosła $3028 \mu \mathrm{g} / \mathrm{m}^{3}$. Narażenie ludności miejskiej na powietrze zanieczyszczone ozonem w Polsce wykazuje umiarkowany trend spadkowy.

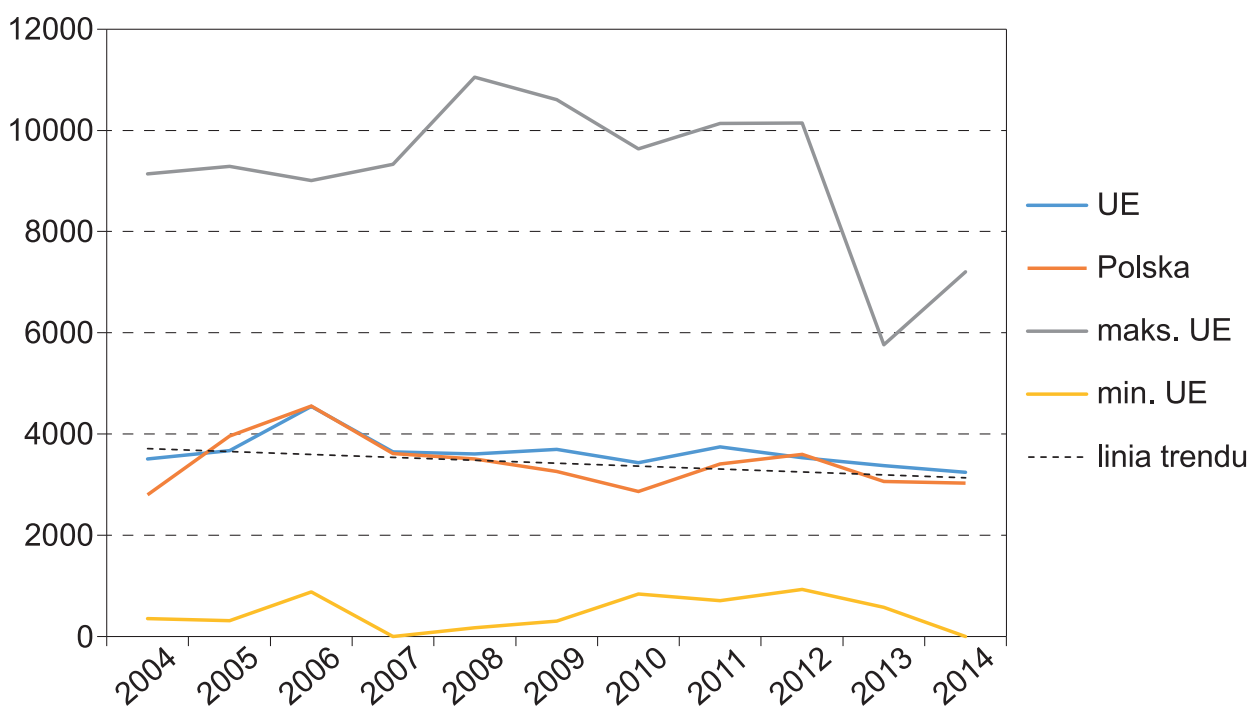

Rysunek 10. Narażenie ludności miejskiej na powietrze zanieczyszczone ozonem $\left(\mu \mathrm{g} / \mathrm{m}^{3}\right)$

Źródło: Eurostat.

\section{Wnioski}

Warto zauważyć, iż zaprezentowane mierniki z dziedziny „zdrowie publiczne” w ładzie społecznym, monitorujące oczekiwane trwanie życia w zdrowiu, umieralność z powodu chorób cywilizacyjnych, wydolność systemu opieki zdrowotnej i narażenie ludności na zanieczyszczenia w powietrzu, składają się na „wskaźnik kardynalny", świadczący o jakości życia danej populacji, jakim jest ogólna liczba ludności (Zalewska 2017, s. 7).

Podczas prac nad rozwojem krajowego zestawu wskaźników zrównoważonego rozwoju kierowano się dążeniem do ładu zintegrowanego poprzez selekcję mierników odnoszących się do więcej niż jednego wzorca do osiągnięcia (= ładu). Tym samym poza wskaźnikami z dziedziny „zdrowie publiczne” w ładzie społecznym mierniki monitorujące trzy pozostałe wzorce do osiągnięcia (ład gospodarczy, środowiskowy oraz instytucjonalno-polityczny) mogą również służyć do pomiaru jakości życia w jej różnych wymiarach. 


\section{Bibliografia}

Borys T. (red.) (2005), Wskaźniki zrównoważonego rozwoju, Warszawa-Białystok.

Brundtland G.H. (2003), Health, poverty and human rights, http://www.who.int/dg/brundtland/ speeches/2003/healthpovertyhumanrights/en/ (dostęp: 25.05.2017).

Długookresowa Strategia Rozwoju Kraju - Polska 2030. Trzecia Fala Nowoczesności, http://monitorpolski.gov.pl/mp/2013/121 (dostęp: 19.11.2017).

Euro Health Consumer Index 2015 Report, http://www.healthpowerhouse.com/publications/eurohealth-consumer-index-2015/ (dostęp: 25.05.2017).

Główny Urząd Statystyczny (GUS) w Katowicach (2015), Wskaźniki zrównoważonego rozwoju Polski 2015, Katowice.

Hanckock T. (1985), Beyond health care: From public health policy to healthy public policy, „The Canadian Journal of Public Health" 76, s. 9-11, http://www.ncchpp.ca/docs/BeyondHealthCare.pdf (dostęp: 5.05.2017).

Konstytucja Światowej Organizacji Zdrowia. Porozumienie zawarte przez Rządy reprezentowane na Międzynarodowej Konferencji Zdrowia i Protokół dotyczący Międzynarodowego Urzędu Higieny Publicznej, podpisane w Nowym Jorku dnia 22 lipca 1946 r., Dz.Urz. UE z 1948 r. Nr 61, poz. 477 z późn. zm., http://isap.sejm.gov.pl/DetailsServlet?id=WDU19480610477 (dostęp: 12.05.2017).

Lalonde M. (1981), A New Perspective on the Health of Canadians, Canada, http://www.phac-aspc. gc.ca/ph-sp/pdf/perspect-eng.pdf (dostęp: 7.05.2017).

Ministerstwo Rozwoju (2017), Cele zrównoważonego rozwoju, https://www.mr.gov.pl/strony/zadania/polityka-rozwoju-kraju/agenda-2030/sdgs/ (dostęp: 25.05.2017).

Narodowy Program Zdrowia (NPZ) na lata 2006-2020, http://www.mz.gov.pl/zdrowie-i-profilaktyka/narodowy-program-zdrowia/npz-2016-2020/cele-operacyjne-npz/ (dostęp: 25.05.2017).

Narodowy Program Zdrowia (NPZ) na lata 2007-2015, http://www.mz.gov.pl/zdrowie-i-profilakty$\mathrm{ka} /$ narodowy-program-zdrowia/npz-2007-2015/determinanty-zdrowia/ (dostęp: 25.05.2017).

Nasza wspólna przyszłość. Raport Światowej Komisji do Spraw Środowiska i Rozwoju (1991), Warszawa.

Przekształcamy nasz świat. Agenda 2030 na rzecz zrównoważonego rozwoju, https://www.mr.gov. pl/strony/zadania/polityka-rozwoju-kraju/agenda-2030/o-agendzie/ (dostęp: 25.05.2017).

Strategia Rozwoju Kapitału Ludzkiego 2020, https://www.mpips.gov.pl/praca/strategie-i-dokumentyprogramowe/strategia-rozwoju-kapitalu-ludzkiego-srkl---projekt-z-31072012-r/ (dostęp: 20.05.2017).

Włodarczyk C. (1996), Polityka zdrowotna w społeczeństwie demokratycznym, Łódź-Kraków-Warszawa.

Wysocki M.J., Miller M. (2003), Paradygmat Lalonde'a. Światowa Organizacja Zdrowia i Nowe Zdrowie Publiczne, „Przegląd Epidemiologiczny” 57, nr 3, s. 505-512, http://www.przeglepidemiol.pzh.gov.pl/paradygmat-lalonde-a-swiatowa-organizacja-zdrowia-i-nowe-zdrowie-publiczne?lang=pl (dostęp: 7.05.2015).

Zalewska M. (2017), Ocena szans realizacji głównych celów strategii Europa 2020 w krajach Grupy Wyszehradzkiej, Międzynarodowy Kongres Naukowy „Zrównoważony rozwój — perspektywy na przyszłość", 19 maja, materiały niepublikowane.

Ekonomia — Wroclaw Economic Review 23/4 (2017)

(C) for this edition by CNS 